\title{
Estampas de América Latina
}

Marcelo Valverde Morales

\section{De Granada a Masaya}

El transporte público en el núcleo del continente es una maraña de gasolina, latas y recuerdos a 100 kilómetros por hora. Donde las gallinas y los niños compiten estirando sus cuellos por la ventana, y donde algunas miradas humedecidas contrastan con las muecas de los menores.

Algunos rostros y voces maltratadas se alzan por encima del motor para ofrecer el grabado de algún santo, chicles o rosarios, al mismo precio de quien intercambia su fe por un plato de respiro.

Las bicicletas son lanzadas al techo, la música es fuerte y el camino un cementerio...

El transporte público en el istmo centroamericano es el recorrido obligatorio de los cuerpos más ásperos al final de la fila...

\section{El jazz de La Habana}

Miramos hacia la nada y reflejamos nuestros rostros, saltamos y empujamos el planeta con los pies.

No podemos explicar cómo el peso de una hoja bota un árbol desde la raíz, pero entendemos la razón por la que los niños entristecen.
Luego caen mis párpados, un gato cojo da pasos por la cocina y las lenguas fragmentan nuestras bocas como péndulos.

Llega una caricia y las que cantan hasta estallar no son las cigarras sino los borrachos; llega mi boca a sus hombros.

La luna suplica por la ventana una escena erótica.

La curvatura de su cuerpo redefine la gravitación de la cama en mi espacio y tiempo...

Entonces dice:

- Cuando entras en mí, vemos por los mismos ojos.

Yo entro y observo.

Caminamos en un mismo cuerpo por la ciudad, de la ventana de un bar se escucha el jazz de La Habana. 


\section{La bahía de Maceió}

Las niñas y las ranas nadan juntas en la bahía de Maceió, donde el tiempo y el esqueleto respiran parcialmente vitalizados.

La arena es fría incluso al mediodía, los hombres tatúan su brazo izquierdo de azul y los peces se ofrecen serenos para alimentar a las bañistas.

La bahía de Maceió me recibió un tres de abril y me enseñó que todo hombre fracasado relega su memoria y sopla una nube para acariciar su cuerpo.

En la bahía de Maceió existió un poeta que cambió poemas por helado de crema.

Las niñas y las ranas nadan juntas en la bahía de Maceió.

\section{Silencio en la montaña}

Las mujeres zapatistas son meteoros que revisten sus rostros, colibríes sangrando la galaxia por arriba de los cerros

Las mujeres zapatistas son los contornos de una bruma que no se disipa jamás.

\section{Desayuno en Antigua / veraneras con romero}

Derramaba el té sobre mi camisa de algodón y yo colocaba nutella en su cuello.

Plantaba margaritas en el florero de mi cráneo para decorar la cocina y yo deslizaba jalea de fresa sobre sus piernas.

$\mathrm{Al}$ anochecer observábamos cómo llueve en la luna, cómo crecen en ella las amapolas.

\section{El cuerpo del campesino}

El cuerpo del campesino centroamericano es un clavo torcido y herrumbrado, que ha sido usado infinitas veces, permaneciendo enloquecido tras el infinito golpe a la cabeza y al pulso del párpado.

El llanto del campesino surge de lo profundo del hueso como un torbellino de piedras.

\section{Las cambistas}

Las cambistas de monedas en la frontera sur de Nicaragua conversan con los turistas sobre el paraje desolado que llevan en el tórax, la erosión pluvial ha desgastado sus voces y sandalias, pero eso de ningún modo desvanecerá su habilidad en las ajustadas cuentas de las raíces que aún quedan. 